\title{
Action research plan to boost participation in college students
}

\author{
Gonzalez-Cuevas, Gustavo'; Rubio, Margarita ${ }^{\mathrm{b}}$; Hernando, Asuncion ${ }^{\mathrm{c}}$; Alvarez, \\ Maria Jose $^{\mathrm{d}}$ and Tavera, Maria Victoria ${ }^{\mathrm{a}}$ \\ ${ }^{\mathrm{a}}$ Department of Psychology, European University of Madrid, Spain, ${ }^{\mathrm{b}}$ School of doctoral \\ studies and research, European University of Madrid, Spain ${ }^{\mathrm{c}}$ Department of Pharmacy and \\ Biotechnology, European university of Madrid, Spain, ${ }^{\mathrm{d} S c h o o l}$ of Health Sciences, \\ Pontifical university of Salamanca, Spain
}

\begin{abstract}
Tackling difficulties related to student participation in the college classroom is central on the learning process. In this action-research study, we designed and implemented an action plan to boost participation on the grounds of (1) explaining the objectives and procedures for each activity to students; (2) requesting student participation by name; (3) giving them time to reflect before participating; and (4) requesting that students who are not paying attention participate. A survey was used in order to assess students' perceptions of the action plan. The questionnaire included 10 items (1-4 Likert scale) and was completed by a total of 103 students. The scores' mean was 3.19, demonstrating a positive student perception of the action plan. The statements with the highest average scores were: "Teacher allows time for reflection after posing a question" and "Teacher addresses specific students by name." The instructors recorded their perceptions into writing, providing opinions on the development of the action plan. These teachers' comments were summarized into categories. In conclusion, we considered that the action plan helped to improve student participation, and we believe that in order to obtain sufficient participation we have to attain a classroom environment that favors motivation, confidence and respect for students.
\end{abstract}

Keywords: Participation, college students, learning climate, action research 


\section{Introduction}

General agreement exists about the importance of participation in university education; for instance, enabling students to become involved in their own learning and enjoy their learning process (O'Connor, 2013). Other benefits of participation include increases in students commitment and better understanding and critical thinking (Heyman and Sailors, 2011). Furthermore, student participation has been shown to encourage active learning, improve work habits and develop specific skills, which are key ingredients for success in the professional world.

Improving participation in the classroom requires instructor awareness of a wide variety of factors that may influence participation. Briefly, we summarize the literature on the topic through the prism of student, instructor and class characteristics.

Student characteristics are central to participation in such a way that older students, students that are more confident, students who care less about their classmates' opinions and students with more teacher contact outside the classroom tend to participate more (Weaver, 2005). Personality variables may also direct interactions in the context of the learning process and have an impact on students' emotional self (Orejudo, Nuño, Fernández, Ramos, \& Herreros, 2007; Rinaudo, Donolo, \& Chiecher, 2002). In this line, students with a higher degree of shyness and introversion may have difficulty participating and some may be afraid to participate in large groups.

A few studies have focused on analyzing student perception of the idea of participation. A majority of students believe that classroom participation contributes to learning, skills and personal development. Students believe that teachers using participative methods show more concern for the students' education and for communication both as amongst students as well as with teachers (Fritschner, 2000; Alkandari, 2012).

Regarding instructors' traits, the ability to foster communication and support students, as well as to provide different points of view on topics being discussed in class, are considered important (Rinaudo et al, 2002). Gender differences in teacher behavior were identified between male and female teachers; female teachers were more likely to provide follow-up, positive verbal reinforcement and feedback and were able to develop a more comfortable environment for participation (Tatum, 2013). Some authors have addressed the difficulty faced by teachers in evaluating participation. In this regard, students usually see a subjective component in such evaluations (Dirk, 2010; Heyman \& Sailors, 2011).

Other factors involve the class. For example, significant differences in participation have also been identified depending on group sizes (Alkandari, 2012). In small groups, students tend to ask more questions, show more interest in the content, think that they are better developing their critical thinking skills and are more satisfied in general with the class 
(Hamann, Pollock \& Wilson, 2012). Moreover, as regards advanced courses, both students and teachers expect it to be participative and act in accordance with that expectation so that teachers encourage participation more and students get more involved. In basic courses participation is usually elicited or initiated by the teacher, whereas in advanced courses, participation is more often initiated by the students themselves (Fritschner, 2000).

Although the importance and factors of participation have been studied previously, infrequent and inadequate participation continue to be a serious problem in our classes. For this study, we implemented an action research plan that would allow us (1) to motivate our students to participate and (2) to assess their perception of this plan. Ultimately, this learning experience may help other educators achieve authentic participation in their students.

\section{Methodology}

Figure 1 summarizes the most significant stages of the action research methodology implemented in this project. In this action-research study, we initially developed a definition of participation based on the scientific literature as well as our personal reflections (Defining the problem situation). The definition reads as follows: "Any type of student engagement in the classroom that gives rise to different interactions with the teacher as well as other classmates."

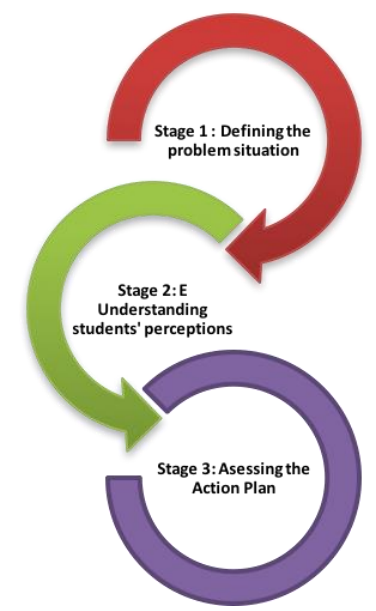

Figure 1. Stages of the action research cycle

Next, we gained a deeper understanding of teacher and student perceptions of participation using a mixed methodology (Tabera, Alvarez, Hernando \& Rubio, 2015) (Understanding the real situation). Then, we designed and implemented an action plan to boost 
participation in college undergraduate students (Action plan). Finally, the effectiveness of the action plan was assessed by self-report measurements and reflective writing (Action plan assessment).

The sample was comprised of the following groups of students: four groups of second-year medical students in the Basic Epidemiology and Applied Biostatistics and Medical Psychology classes; one group of first-year Criminology students in the Quantitative and Qualitative Research Techniques class; one group of third-year Criminology and Law students in the Quantitative and Qualitative Research Techniques class; one group of firstyear Psychology and Criminology students in the Sensation, Perception and Attention class; one group of second-year Psychology students in the Motivation and Emotions class.

Prior to implementing this plan, each teacher held an information session where they provided students with an explanation of the research project to be carried out and, in particular, of the objectives of the action plan to increase participation. Students were informed that starting that week an action plan would be implemented in their classes, which would include the following four actions:

\section{(1) explaining the objectives and procedures for each activity to students}

(2) requesting student participation by name

\section{(3) giving them time to reflect before participating}

\section{(4) requesting that students who are not paying attention participate}

After the action plan was detailed to the students, discussion was held on the topic and agreement on implementation of the proposed actions achieved. The duration of the action plan differed for the groups of students but, in any case, lasted at least one month. After the action plan was implemented in the classrooms, a survey was used in order to assess students' perceptions of the action plan. The survey included 10 items (see Table 1) to be evaluated on a Likert scale based on the extent to which the participant agreed (1 being the lowest agreement and 4 the highest agreement).

After having reflected upon the experience, the instructors that participated in this experience recorded their perceptions into writing, providing opinions on the development of the action plan, students' comments and all other additional comments. 


\section{Results}

The action plan assessment was performed by both students and teachers.

\subsection{Students' evaluation}

A total of 103 students completed the survey on an anonymous basis. Of these students, 57 were enrolled in a bachelor's program in Medicine (55.3\%), 20 (19.4\%) in Psychology, 9 $(8.7 \%)$ in Psychology and Criminology, 8 (7.8\%) in Criminology, 6 (5.8\%) in Education and Psychology and 3 (2.9\%) in Law and Criminology. A majority of the students (92; $89.3 \%$ ) were in their second year, $8(7.8 \%)$ were in their first year and $3(2.9 \%)$ were in their third year.

The survey results are provided in Table 1. An average and standard deviation (SD) for the score for each item was calculated.

Table 1. Survey results on student perception of the action plan

\begin{tabular}{|c|c|}
\hline Average \pm SD & \\
\hline 1. Do you think this intervention improved your participation? & $3.01 \pm 0.69$ \\
\hline $\begin{array}{l}\text { On a scale of } 1 \text { to } 4 \text {, how much did each of the following contribute to improving } \\
\text { participation: }\end{array}$ & \\
\hline 2. Clearly describing the type of participation requested & $3.03 \pm 0.57$ \\
\hline 3. Teacher addresses specific students by name & $3.40 \pm 0.78$ \\
\hline 4. Clearly describing what is expected of students as regards participation & $3.20 \pm 0.70$ \\
\hline 5. Teacher addresses distracted students to "help them return" to class & $2.99 \pm 0.95$ \\
\hline 6. Teacher allows time for reflection after posing a question & $3.41 \pm 0.72$ \\
\hline $\begin{array}{l}\text { 7. Did you feel more comfortable participating after we implemented these } \\
\text { measures? }\end{array}$ & $2.87 \pm 0.81$ \\
\hline 8. Did you find that the teacher's attitude encouraged you to participate? & $3.29 \pm 0.68$ \\
\hline 9. Did the class have a respectful attitude that encouraged participation? & $3.30 \pm 0.67$ \\
\hline 10. Did you have a respectful attitude that encouraged participation? & $3.38 \pm 0.72$ \\
\hline
\end{tabular}

The scores' mean was 3.19 (range:1-4), demonstrating a positive student perception of the action plan. As shown in table 1, the statements with the highest average scores were: "Teacher allows time for reflection after posing a question" and "Teacher addresses specific students by name." The statement with the lowest average score was "Did you feel more comfortable participating after we implemented these measures?" The statement with the highest variability in the responses was "Teacher addresses distracted students to 'help them return' to class." 
The answers to questions 8, 9 and 10 show that teachers' and students' attitudes seem to be appropriate and respectful, which leads us to believe that this action plan was effective in improving the classroom environment.

\subsection{Teachers' evaluation}

The instructors that participated in this experience recorded their perceptions into writing, providing opinions on the development of the action plan, students' comments and all other additional comments. These teachers' comments were summarized into the categories shown in Table 2.

Table 2. Categorization of teachers' comments on the experience

\begin{tabular}{|c|c|}
\hline CATEGORIES & \\
\hline $\begin{array}{l}\text { 1.- Student comments on participation } \\
\text { before implementing the action plan }\end{array}$ & $\begin{array}{l}\text { - Not all teachers encourage participation } \\
\text { - Although some instructors encourage participation, in the end, that } \\
\text { doesn't happen because they don't provide enough time to } \\
\text { participate } \\
\text { - Participation is frequently requested but feedback is not provided } \\
\text { - Teachers ask for their opinion but don't actually take it into } \\
\text { account when making decisions } \\
\text { - Some students stated that participation should be voluntary, } \\
\text { because everyone is different } \\
\text { - In general, they believe that participation is necessary and has } \\
\text { advantages } \\
\text { - Some students indicated that they believed inviting distracted } \\
\text { students to participate was too harsh } \\
\text { - Not all teachers make participation objectives clear }\end{array}$ \\
\hline 2.- Explanation of the procedure & $\begin{array}{l}\text { - The various actions of the activity were described to the groups } \\
\text { - Students discussed the action plan } \\
\text { - Students were asked for their opinion regarding the process as a } \\
\text { whole } \\
\text { - Students completed a survey at the end of the activity }\end{array}$ \\
\hline $\begin{array}{l}\text { 3.- Teacher perception of the action } \\
\text { plan }\end{array}$ & $\begin{array}{l}\text { - Improved the learning environment. } \\
\text { - Improved relationships with students and the classroom } \\
\text { environment. } \\
\text { - Brought students and teachers closer together. } \\
\text { - Required effort by both teachers and students. } \\
\text { - Improved the use of class time. } \\
\text { - Expressing our interest in their participation and gathering their } \\
\text { opinions has a very positive effect. } \\
\text { - Students value when teachers seek and take their opinion into } \\
\text { account. } \\
\text { - Fostered student satisfaction. } \\
\text { - It's critical to explain the specific actions of the plan and make } \\
\text { sure its objectives are clear. }\end{array}$ \\
\hline 4.- Effective messages to reinforce & - "It doesn't matter if you're wrong" \\
\hline
\end{tabular}




\begin{tabular}{|l|l|}
\hline participation & $\begin{array}{l}\text { - "The important thing is that you learn" } \\
\text { - "Thank you for sharing your opinion" }\end{array}$ \\
\hline $\begin{array}{l}\text { 5.- Teacher proposals to improve } \\
\text { participation (post-action plan) }\end{array}$ & $\begin{array}{l}\text { - A warm and nurturing environment to encourage participation } \\
\text { must be established } \\
\text { - Confidence must be instilled in students } \\
\text { - Participation has to be regarded as central to active learning } \\
\text { - Importance of errors has to be ameliorated. }\end{array}$ \\
\hline
\end{tabular}

\section{Discusion}

All in all, the action plan helped to improve student participation as evaluated by both students and instructors. It was focused on these specific actions: (1) explaining the objectives and procedures for each activity to students; (2) requesting student participation by name; (3) giving them time to reflect before participating; (4) requesting that students who are not paying attention participate.

Specifically, our results suggest that when implementing a classroom participation action plan, it is essential to clearly explain the objectives and procedures to be followed ahead of time. Discussing the actions to be implemented with students could also mean increased student engagement, as they value when their opinions are taken into account.

We also collected evidence showing that this action plan may have increased classroom participation primarily because the students perceived a caring approach of the instructor (high score on the item: "teacher addresses specific students by name"), who also provided enough time to reflect before responding (high score on the item: "teacher allows time for reflection after posing a question").

Requesting participation may have obligated students, especially those usually being distracted in the classroom, to make an effort when they were presented with new activities. For this reason, students might need time to reflect before participating. In this line, a low score for the item "Did you feel more comfortable participating after we implemented these actions?" could be a reflection of the students need for more time to internalize these actions.

In addition to a boost in student participation, this action plan produced a benefitial effect on classroom environment, which can be understood as the perception of factors related to characteristics of both teachers and the environment that provide students with the necessary security to engage in their learning. Perceptions of the relationships between students and the teacher, as well as amongst students, seemed to have gotten better in the groups where the plan was implemented. As a result, it is reasonable to think that generating an environment that promotes trust, confidence and respect for students must be 
a top priority for instructors if authentic participation is to be achieved. It is worth noting, though, that implementing these actions may require extra work by teachers and students.

\section{References}

Alkandari, N. (2012). Students' communication and positive outcomes in college classrooms. Education, 133(1), 19-30.

Dirk, K. (2010). "I hope it's just attendance": what does participation mean to freshman composition students and instructors? Composition Studies, 38(1), 88-105.

Fritschner, L. (2000). Inside the undergraduate college classroom. Students and faculty differ on the meaning of classroom participation. Journal of Higher Education, 7(1), 342-362.

Hamann, K., Pollock, P. H. and Wilson, B.M. (2012). Assessing student perceptions of the benefits of discussions in small-group, large-class, and online learning contexts. College Teaching, 60, 65-75.

Heyman, J., Sailors, J.J. (2011). Peer assessment of class participation: applying peer nomination to overcome rating inflation. Assessment and Evaluation in Higher Education, 36(5), 605-618.

O'connor, K.J. (2013). Class participation: promoting in-class student engagement. Education, 133(3), 340-344.

Orejudo, S., Nuño, J., Fernandez, T., Ramos, M.T., Herreros, M.L. (2007). Participación del alumnado universitario en el aula. Una investigación sobre el temor a hablar en público en grandes grupos. Revista Interuniversitaria de Formación del Profesorado, 21(1), 145-160.

Rinaudo, M.C., Donolo, D., Chiecher, A. (2002). La participación en clases universitarias. Evaluación desde la perspectiva del alumno. Cuadernos FHYCS-UNJu. 15, 77-88.

Tatum, H.E. (2013). Classroom participation and student-faculty interactions: does gender matter? The Journal of Higher Education, 84(6), 745-768.

Weaver, R.R., Qi, J. (2005). Classroom Organization and Participation: College Students' Perceptions. The Journal of Higher Education, 76(5), 570-601. 